\title{
PENGARUH PROTEIN PAKAN YANG BERBEDA TERHADAP KOEFISIEN KECERNAAN NUTRIEN SERTA PERFORMANSI BIOLOGIS KERAPU MACAN, Epinephelus fuscoguttatus DALAM KERAMBA JARING APUNG
}

\author{
Asda Laining, Naftali Kabangnga, dan Usman
}

\begin{abstract}
ABSTRAK
Penelitian untuk mengetahui kebutuhan protein pakan optimal dan pengaruhnya terhadap nilai kecernaan serta respon biologi ikan kerapu macan telah dilakukan di keramba jaring apung. Pakan uji dengan kandungan protein berbeda yaitu $35 \%, 40 \%, 45 \%, 50 \%$, dan $55 \%$ diberikan pada ikan kerapu macan yang dipelihara dalam keramba jaring apung di laut selama 126 hari. Ikan kerapu macan diperoleh dari unit perbenihan di Balai Besar Riset Perikanan Budidaya Laut, Gondol-Bali dan dikelompokkan berdasarkan ukuran bobot awal menjadi 3 kelompok yaitu kelompok kecil (53--65 g), kelompok sedang (75--85 g), dan kelompok besar (97--105 g). Ikan ditebar dalam 15 unit keramba ukuran $1 \times 1 \times 2,5 \mathrm{~m}^{3}$ masing-masing sebanyak 12 ekor/keramba. Percobaan dirancang dengan Rancangan Acak Kelompok dengan 5 perlakuan masing-masing 3 ulangan. Penentuan koefisien kecernaan pakan dilakukan dengan menggunakan kromium oksida sebagai indikator dan pengumpulan feses dilakukan dengan metode sedimentasi menggunakan tanki kerucut. Hasil yang diperoleh menunjukkan bahwa pakan dengan kandungan protein $50 \%$ memberikan respon biologis yang terbaik pada ikan kerapu macan di mana nilai pertambahan bobot, pertumbuhan mutlak, sintasan, dan efisiensi pakan yang diperoleh masingmasing adalah $266,2 \% ; 1,7 \mathrm{~g} /$ hari; $72,2 \%$; dan $78,6 \%$. Koefisien kecernaan protein pakan berbeda nyata $(P<0,05)$ antar perlakuan di mana angka tertinggi diperoleh pada pakan dengan protein $50 \%(80,96 \%)$; sedangkan koefisien kecernaan bahan keringnya tidak berbeda nyata $(P>0,05)$ antar perlakuan. Berdasarkan broken-line analysis terhadap nilai pertambahan bobot ikan, kebutuhan protein optimum untuk kerapu macan ukuran $80--300 \mathrm{~g}$ adalah $50,9 \%$.
\end{abstract}

\begin{abstract}
The effect of dietary protein level on apparent digestibility coefficient and biological performances of tiger grouper, Epinephelus fuscoguttatus raised at floating net cages. By:Asda Laining, Naftali Kabangnga, and Usman
\end{abstract}

An experiment was carried out to obtain the appropriate dietary protein including its effects on apparent protein digestibility coefficient and biological responses of tiger grouper. Tested diets containing different levels protein namely $35 \%, 40 \%, 45 \%, 50 \%$, and $55 \%$ were given to tiger grouper raised at sea floating cages for 126 days. Tiger grouper were transferred from Research Institute for Mariculture, Gondol-Bali and selected into three different weight groups namely small $(53--65 \mathrm{~g})$, middle $(75--85 \mathrm{~g})$, and big $(97-105 \mathrm{~g})$. Fish were stocked into fifteen $1 \times 1 \times 2.5 \mathrm{~m}^{3}$ cages in a density of 12 fish for each cage. This experiment was designed into Randomized Block, five treatments with triplicates. Determination of apparent digestibility coefficient used cromium oxide as innert marker, while faecal collection was done using sedimentation method with conicle tank. The results showed that diet containing 50\% protein gave the best biological responses, where the values of weight gain, absolute growth, survival rate, and feed efficiency were $266.2 \%$, $1.7 \mathrm{~g} /$ day, $78.6 \%$ respectively. Its Then, apparent protein digestibility coefficient was significantly different compared to the other diets $(P<0.05)$ and was the highest $(80.96 \%)$. Meanwhile, apparent dry matter digestibility coefficients were not significantly different among treatments $(P>0.05)$. Based on broken line-analysis for weight gain value, optimum dietary protein level of tiger grouper of $80--300 \mathrm{~g}$ was $50.9 \%$.

KEYWORDS: protein, digestibility coefficient, growth, tiger grouper

Peneliti pada Balai Riset Perikanan Budidaya Air Payau, Maros 


\section{PENDAHULUAN}

Ikan kerapu bebek, kerapu macan, maupun spesies kerapu lainnya merupakan jenis-jenis ikan laut yang banyak dijadikan komoditas budi daya, karena harga jualnya yang tinggi. Keberhasilan unit perbenihan dalam memproduksi benih secara massal baik benih kerapu bebek maupun kerapu macan mendorong berkembangnya usaha pembesaran ikan ini khususnya dalam keramba jaring apung.

Secara umum hewan air seperti ikan dan krustase terutama yang habitatnya di laut membutuhkan protein yang tinggi untuk dapat tumbuh dengan baik (NRC, 1993). Secara spesifik ikan-ikan membutuhkan protein optimum yang berbeda tergantung pada spesies dan stadia, di mana stadia larva dan benih membutuhkan protein yang tinggi dan sebaliknya pada stadia pembesaran (Boonyaratpalin, 1991). Beberapa penelitian mengenai kebutuhan nutrisi spesies kerapu sudah dilakukan. Kebutuhan protein dalam pakan yuwana kerapu Epinephelus striatus diketahui lebih dari 55\% (Ellis et al., 1996); E. akaara 49,5\% (Chen et al., 1995); E. malabaricus $47,8 \%$ (Chen \& Tsai, 1994), sedangkan kebutuhan protein untuk kerapu bebek (Cromileptes altivelis) ukuran $5,5 \mathrm{~g}$ adalah $54,2 \%$ (Giri et al., 1999), dan pada ukuran $17 \mathrm{~g}$ dibutuhkan 50,1\% (Rachmansyah et al., 2001). Selain kebutuhan protein, dilaporkan pula bahwa ikan kerapu bebek memerlukan lemak dalam pakannya antara $9 \%$ $-11 \%$, vitamin $\mathrm{C}$ berbentuk L-ascorbyl-2-monophosphate-Na-Ca sebanyak $150 \mathrm{mg} / \mathrm{kg}$ pakan (Laining et al., 2002). Kerapu bebek mampu memanfaatkan glukosa sebagai sumber karbohidrat pada kadar $16 \%$ (Usman, 2002). Sementara itu, informasi mengenai kebutuhan protein maupun kebutuhan nutrisi lainnya pada ikan kerapu macan belum banyak diketahui, terutama untuk pembesaran di keramba jaring apung.

Penelitian ini bertujuan untuk mendapatkan kadar protein optimum pakan untuk pembesaran ikan kerapu macan di keramba jaring apung laut, sebagai informasi dasar dalam upaya pengembangan pakan buatannya.

\section{BAHAN DAN METODE}

\section{Pengamatan Respon Biologi Ikan}

Ikan kerapu macan diperoleh dari unit perbenihan di Gondol, Bali dan diadaptasikan selama satu minggu dalam keramba jaring apung di Teluk Labuange, Kabupaten Barru, Sulawesi Selatan. Ikan selanjutnya diseleksi dan dikelompokkan berdasarkan ukuran bobot menjadi 3 yaitu kelompok kecil (53--65 g), kelompok sedang (75--85 g), dan kelompok besar (97$-105 \mathrm{~g})$. Ikan ditebar sebanyak 12 ekor/keramba ukuran $1 \times 1 \times 2,5 \mathrm{~m}^{3}$. Mengingat ukuran ikan yang tidak seragam, maka percobaan ini disusun dengan menggunakan Rancangan Acak Kelompok dengan 3 ulangan.

Perlakuan yang dicobakan adalah 5 jenis pakan dengan kandungan protein yang berbeda yaitu $35 \%$, $40 \%, 45 \%, 50 \%$, dan $55 \%$. Formulasi pakan disajikan pada Tabel 1 dengan memanfaatkan bahan baku lokal yang dikombinasikan dengan bahan impor. Pakan dibuat dalam bentuk pelet kering ukuran 3--7 mm yang disesuaikan dengan ukuran ikan. Pakan diberikan dua kali sehari pada pukul $08 . .^{00}$ dan $17 .{ }^{\circ 0}$ WITA secara satiasi.

Analisis proksimat bahan dasar pakan digunakan untuk menentukan kandungan nilai nutrisi pakan

Tabel 1. Formulasi pakan percobaan $(\mathrm{g} / \mathrm{kg})$

Table 1. Formulation of experimental diets $(\mathrm{g} / \mathrm{kg})$

\begin{tabular}{lccccc}
\hline \multirow{1}{*}{$\begin{array}{c}\text { Bahan } \\
\text { Ingredients }\end{array}$} & \multicolumn{5}{c}{ Kadar protein (Protein levels) } \\
\cline { 2 - 6 } & $\mathbf{3 5}$ & $\mathbf{4 0}$ & $\mathbf{4 5}$ & $\mathbf{5 0}$ & $\mathbf{5 5}$ \\
\hline Tepung ikan (Fish meal) & 440 & 500 & 560 & 620 & 680 \\
Wheat gluten & 128 & 146 & 164 & 182 & 200 \\
Tepung rebon (Mysid meal) & 20 & 20 & 20 & 20 & 20 \\
Dedak halus (Rice brand) & 60 & 45 & 30 & 15 & 0 \\
Pati jagung (Com starch) & 228 & 171 & 114 & 57 & 0 \\
Minyak ikan (Fish oil) & 24 & 18 & 12 & 6 & 0 \\
Minyak cumi (Squid oil) & 70 & 70 & 70 & 70 & 70 \\
Campuran vitamin (Vitamin mix) & 20 & 20 & 20 & 20 & 20 \\
Campuran mineral (Mineral mix) & 10 & 10 & 10 & 10 & 10 \\
L-ascorbyl-2-phosphate-Na-Ca*1 & 0.1 & 0.1 & 0.1 & 0.1 & 0.1 \\
\hline
\end{tabular}

"Ditambahkan berdasarkan pengurangan pati jagung

${ }^{-}$Added at the expense to corn starch 
Tabel2. Komposisi nutrisi pakan percobaan (\% bobot kering)

Table 2. Chemical composition of experimental diets (\% dry matter)

\begin{tabular}{lrrrrr}
\hline \multirow{1}{*}{$\begin{array}{c}\text { Nutrien } \\
\text { Nutrients }\end{array}$} & \multicolumn{5}{c}{ Kadar protein (Protein levels) (\%) } \\
\cline { 2 - 6 } & $\mathbf{3 5}$ & $\mathbf{4 0}$ & $\mathbf{4 5}$ & $\mathbf{5 0}$ & $\mathbf{5 5}$ \\
\hline Protein kasar (Crude protein) & 35.9 & 41.1 & 45.4 & 50.6 & 55.5 \\
Lemak kasar (Crude lipid) & 10.4 & 9.9 & 9.5 & 9.7 & 9.6 \\
Abu (Ash) & 17.0 & 18.1 & 19.0 & 19.1 & 20.1 \\
Serat kasar (Crude fibre) & 0.5 & 0.7 & 1.0 & 1.1 & 0.8 \\
Karbohidrat (NFE) & 36.2 & 30.2 & 25.1 & 19.5 & 14.0 \\
Total energi (Gross energy (cal/g) ${ }^{*}$ ) & 4495.4 & 4495.9 & 4492.0 & 4575.1 & 4617.0 \\
\hline
\end{tabular}

* Total energi dihitung berdasarkan nilai konversi protein: 5,65 kkal/g; lemak 9,45 kkal/g; dan karbohidrat $4,10 \mathrm{kkal} / \mathrm{g}$ (NRC, 1993) * Gross energy is calculated based on conversion value for protein: $5.65 \mathrm{kcal} / \mathrm{g}$; lipid $9.45 \mathrm{kcal} / \mathrm{g}$; and
carbohydrate $4.10 \mathrm{kcal} / \mathrm{g}$

dalam kegiatan formulasi, juga terhadap pakan hasil formulasi. Analisis proksimat meliputi kadar air (pengeringan dalam oven pada suhu $110^{\circ} \mathrm{C}$ ), protein kasar (semi-micro Kjeldhal), lemak kasar (Soxhletekstraksi dengan petroleoum benzen), serat kasar (Fibretex), dan abu (pemanasan dengan Muffle-furnace pada $550^{\circ} \mathrm{C}$ ).

Pengukuran panjang dan penimbangan bobot ikan dilakukan setiap 21 hari. Parameter biologi yang diukur adalah pertambahan bobot, laju pertumbuhan, sintasan, konsumsi pakan, dan efisiensi pakan. Analisis beda nyata dari data yang diperoleh dilakukan berdasar uji LSD (least significant difference). Penentuan level optimum protein dengan membuat broken-line analisis terhadap nilai parameter pertambahan bobot ikan (Jobling, 1994).

\section{Penentuan Koefisien Kecernaan Pakan}

Kegiatan ini dilakukan setelah pengamatan respon biologis ikan berakhir. Komposisi pakan yang digunakan sama dengan pengamatan pertama tetapi ditambahkan kromium oksida sebanyak $1 \%$ sebagai indikator. Jumlah keramba yang digunakan sebanyak 5 unit dengan kepadatan ikan uji masing-masing 10 ekor/keramba. Sebelum feses dikumpulkan, ikan diadaptasikan terlebih dahulu dengan pakan uji selama 5 hari. Feses dikumpulkan dengan metode sedimentasi menggunakan tank konikel yang dilengkapi tabung kecil di bawahnya sebagai penampung feses. Pengumpulan feses dilakukan selama 3--5 hari tergantung jumlah sampel yang dibutuhkan untuk analisis kimia. Pengumpulan feses ini dilakukan sebanyak dua kali sebagai ulangan pengamatan. Feses selanjutnya dikeringkan dalam oven pada suhu $40^{\circ} \mathrm{C}$ dan disimpan dalam botol vial pada suhu $-10^{\circ} \mathrm{C}$ sampai analisis dilakukan.

Analisis proksimat untuk feses hanya meliputi kadar air dan protein (AOAC, 1990). Analisis kadar kromium pada pakan dan feses dilakukan dengan prosedur Furukawa \& Tsukahara (1966) dengan pembacaan hasil akhir menggunakan

Tabel 3. Rata-rata koefisien kecernaan pakan (\%, SD) dengan kandungan protein berbeda pada ikan kerapu macan (Epinephelus fuscoguttatus)

Table 3. Apparent digestibility coefficient of diet $(\%, S D)$ containing different protein levels in tiger grouper (Epinephelus fuscoguttatus)

\begin{tabular}{|c|c|c|c|c|c|}
\hline \multirow{2}{*}{$\begin{array}{c}\text { Koefisien kecernaan } \\
\text { Apparent digestibility coefficient }\end{array}$} & \multicolumn{5}{|c|}{ Kadar protein (Protein levels) (\%) } \\
\hline & 35 & 40 & 45 & 50 & 55 \\
\hline $\begin{array}{l}\text { Koefisien kecernaan bahan kering } \\
\text { Apparent dry matter digest. coefficient } \\
\text { Koefisien kecernaan protein }\end{array}$ & $47.33^{a^{*}} \pm 2.36$ & $50.49^{a} \pm 3.84$ & $48.50^{a} \pm 4.01$ & $53.90^{a} \pm 4.21$ & $50.28^{a} \pm 0.83$ \\
\hline Apparent protein digest.coefficient & $72.15^{\mathrm{a}} \pm 1.25$ & $71.66^{a} \pm 0.62$ & $76.59^{b} \pm 1.82$ & $80.96^{c} \pm 0.17$ & $79.86^{c} \pm 1.29$ \\
\hline
\end{tabular}

* Nilai dalam baris yang sama dan diikuti oleh huruf yang sama tidak berbeda nyata $(P>0,05)$

* Value in rows followed by the same superscript are not significantly different $(P>0.05)$ 
spektrofotometer Shimadzu UV-VIS 2401 PC. Perhitungan nilai kecernaan pakan dihitung berdasarkan rumus:

$$
\mathrm{NK}_{p}(\%)=100 \times\left\{1-\left(\mathrm{N}_{\mathrm{i}} / \mathrm{N}_{\mathrm{f}}\right) \times\left(\mathrm{I}_{\mathrm{f}} / \mathrm{I}_{\mathrm{pi}}\right)\right\}
$$

dengan:

$\mathrm{NK}_{\mathrm{p}} \quad$ : nilai kecernaan

$N_{p}$ dan $N_{f}$ : nutrien (protein) dalam pakan dan feses

$\mathrm{I}_{\mathrm{p}}$ dan $\mathrm{I}_{\mathrm{f}}$ : indikator dalam pakan dan feses

(Forster, 1999)

\section{HASIL DAN BAHASAN}

Koefisien kecernaan protein dan bahan kering pakan yang diperoleh relatif sama antar perlakuan, masing-masing berkisar antara $71,66 \%--80,96 \%$ dan $47,33 \%--53,90 \%$. Koefisien kecernaan protein cenderung meningkat dengan meningkatnya kadar protein dalam pakan di mana nilai tertinggi diperoleh pada pakan dengan protein $50 \%$ yaitu $80,9 \%$, tidak berbeda nyata dengan pakan berprotein $55 \%$ tetapi berbeda nyata dengan ketiga pakan lainnya $(P<0,05)$ (Tabel 3). Koefisien kecernaan protein pakan di atas dapat menjadi gambaran peluang pemanfaatan protein pada ikan kerapu macan. Koefisien kecernaan bahan kering tertinggi pada pakan dengan protein $50 \%$ yaitu $53,90 \%$ dan terendah pada pakan dengan protein $35 \%(47,33 \%)$ tetapi tidak ada perbedaan yang nyata di antara semua perlakuan $(P>0,05)$.

Pertambahan bobot ikan selama pemeliharaan 126 hari meningkat secara nyata $(P<0,05)$ dengan meningkatnya kandungan protein pakan. Pertambahan bobot terendah terlihat pada ikan yang diberi pakan berprotein $35 \%$ yaitu $77,2 \%$ dan tertinggi pada ikan yang diberi pakan dengan protein $50 \%$ sebesar $210,9 \%$ (Tabel 4). Ikan yang diberi protein pakan $35 \%$ pertambahan bobotnya tidak berbeda nyata dengan protein $40 \%$.

Pola pertambahan bobot ikan relatif sama dengan pola pertumbuhan mutlaknya di mana pakan dengan protein $35 \%$ memberikan pertumbuhan yang tidak berbeda nyata dengan protein $40 \%(P>0,05)$ tetapi berbeda nyata dengan kadar protein pakan yang lebih tinggi. Pola pertumbuhan tersebut dapat dilihat dengan jelas pada Gambar 1 yang menggambarkan pertambahan bobot rata-rata individu ikan dari masingmasing perlakuan. Pada gambar ini terlihat bahwa sampai pada hari ke-105, pertambahan bobot ikan tertinggi terjadi pada pakan yang kandungan proteinnya $55 \%$ tetapi cenderung mulai menurun sampai hari ke-126. Ikan yang diberi pakan berprotein $50 \%$ pertambahan bobotnya lebih tinggi dibandingkan dengan pakan dengan 55\%. Meskipun berdasarkan analisis statistik pertumbuhan ikan tidak dipengaruhi oleh perbedaan kelompok ukuran ikan pada kadar protein yang sama, dari Gambar 1 dapat terlihat bahwa kadar protein yang memberikan pertumbuhan lebih baik mulai hari ke-105 diduga disebabkan oleh bertambahnya ukuran ikan. Apabila masa pemeliharaan dilanjutkan lebih lama kemungkinan kadar protein yang terbaik pada percobaan ini dapat lebih rendah dari $50 \%$ di mana bobot ikan bertambah seiring dengan bertambahnya umur ikan.

Menurut Halver (1989), faktor yang mempengaruhi kebutuhan protein pada spesies ikan yang sama adalah ukuran dan umur serta suhu lingkungan.

Tabel 5. Performansi biologi ikan kerapu macan yang diberi pakan dengan kadar protein yang berbeda Table 5. Biological performances of tiger grouper fed different levels of protein

\begin{tabular}{lccccc}
\hline \multirow{2}{*}{$\begin{array}{c}\text { Parameter biologi } \\
\text { Biological parameters }\end{array}$} & \multicolumn{5}{c}{ Kadar protein (Protein levels) (\%) } \\
\cline { 2 - 6 } & 35 & 40 & 45 & 50 & 55 \\
\hline Bobot awal (Initial weight) (g) & 82.6 & 80.6 & 81.8 & 80.7 & 80.4 \\
Bobot akhir (Final weight) (g) & 145.9 & 156.7 & 210.3 & 298.3 & 250 \\
Pertambahan bobot (Weight gain) (\%) & $77.2^{\mathrm{a} 3}$ & $94.9^{\mathrm{a}}$ & $158.6^{\mathrm{b}}$ & $266.2^{\mathrm{d}}$ & $210.9^{\mathrm{c}}$ \\
Pertumbuhan mutlak (Absolute growth) (g/d) & $0.5^{\mathrm{a}}$ & $0.6^{\mathrm{a}}$ & $1.0^{\mathrm{b}}$ & $1.7^{\mathrm{d}}$ & $1.3^{\mathrm{c}}$ \\
Sintasan (Survival rate) (\%) & $41.7^{\mathrm{a}}$ & $44.4^{\mathrm{a}}$ & $50^{\mathrm{ab}}$ & $72.2^{\mathrm{c}}$ & $61.1^{\mathrm{bc}}$ \\
Konsumsi pakan (Feed intake) (g/) $)^{1}$ & $168.6^{\mathrm{a}}$ & $176.9^{\mathrm{a}}$ & $200^{\mathrm{ab}}$ & $274.2^{\mathrm{c}}$ & $255.2^{\mathrm{bc}}$ \\
Efisiensi pakan (Feed efficiency) (\%) & $37.4^{\mathrm{a}}$ & $48.8^{\mathrm{a}}$ & $64.3^{\mathrm{b}}$ & $78.6^{\mathrm{c}}$ & $71.3^{\mathrm{bc}}$ \\
\hline
\end{tabular}

1. Konsumsi pakan: Total pakan harian yang diberikan / 0,5 $\times$ (total ikan di awal dan akhir percobaan) Feed intake: Total daily feed intake/ $0.5 \times$ (total fish at start + total fish at the end)

2. Efisiensi pakan: Pertambahan bobot (g)/ konsumsi pakan (g) $\times 100 \%$

Feed efficiency: Weight gain (g)/ feed intake $(g) \times 100 \%$

3. Nilai dalam baris yang sama dan diikuti oleh huruf yang sama tidak berbeda nyata $(P>0,05)$ Value in rows followed by the same superscript are not significantly different $(P>0.05)$ 


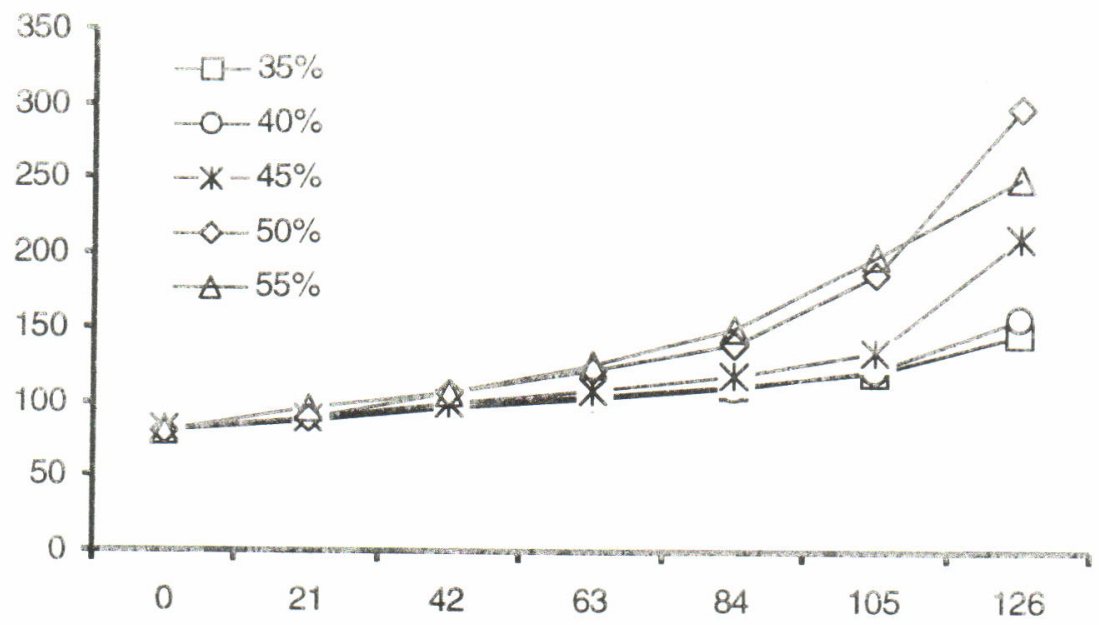

Gambar 1. Peitambahan bobot rataan individu ikan kerapu macan selama 126 hari

Figure 1. Average individual weight gain of tiger grouper after 126 days culture

Kebutuhan optimum protein untuk larva salmon adalah $45 \%--50 \%$, sementara untuk yuwana membutuhkan $40 \%$, dan ikan dewasa protein pakannya sekitar $35 \%$ (NRC, 1981). Perbedaan tingkat kebutuhan protein karena pengaruh umur diduga karena terjadinya perubahan aktivitas enzim pencernaan yang juga dipengaruhi oleh umur ikan, kondisi fisiologi, dan musim. Kitamikado \& Tachino (1960) dalam Hepher (1988) mengemukakan bahwa aktivitas amilolitik pada ikan rainbow trout muda cukup tinggi dan meningkat sampai pada titik puncaknya dengan ukuran $100 \mathrm{~g}$, dan kemudian menurun pada ikan yang lebih besar. $\mathrm{Hal}$ yang serupa terjadi pada aktivitas enzim proteolitik (Morishita et al., 1964 dan Stroganov \& Buzinova, 1969 dalam Hepher (1988). Perubahan aktivitas enzim tersebut dapat diindikasikan oleh nilai koefisien kecernaan protein yang diperoleh pada percobaan ini di mana koefisien kecernaan pakan berprotein $55 \%$ sedikit lebih rendah $(79,8 \%)$ dibandingkan dengan pakan berprotein $50 \%$ yaitu $81 \%$ meskipun kedua nilai tersebut tidak berbeda nyata.

Jumlah konsumsi pakan meningkat seiring dengan meningkatnya kadar protein dalam pakan sampai kadar $50 \%$ tetapi pada pakan berkadar protein $55 \%$, jumlah konsumsinya menurun. Begitu pula dengan efisiensi pakan, meningkat dari $37,4 \%$ pada pakan dengan protein $35 \%$ menjadi $78,6 \%$ pada pakan dengan protein $50 \%$. Selain dipengaruhi oleh kadar protein yang berbeda, berdasarkan analisis statistik, konsumsi pakan juga dipengaruhi oleh bobot ikan.

Pemberian pakan dengan kadar protein berbeda selama 126 hari ternyata sangat berpengaruh terhadap nilai sintasan ikan. Sintasan ikan yang diberi pakan dengan protein $35 \%$ dan $40 \%$ relatif sama masingmasing 41,7\% dan 44,4\%; sedangkan ikan yang diberi protein lebih tinggi sintasannya pun cenderung naik di mana nilai tertinggi diperoleh pada pakan dengan protein $50 \%$ yaitu $72,2 \%$ diikuti oleh pakan dengan protein $55 \%$ sebesar $61,1 \%$. Rendahnya sintasan pada pakan berprotein rendah diduga karena kekurangan protein yang diketahui sebagai komponen nutrisi utama yang berperan dalam proses pertumbuhan (Halver, 1989). Selain itu kurangnya protein ini akan menghambat pertumbuhan ikan dan dapat mengakibatkan kematian.

Berdasarkan broken-line analysis terhadap data pertambahan bobot ikan diperoleh bahwa kebutuhan protein optimum untuk kerapu macan dari ukuran 80 $-300 \mathrm{~g}$ adalah 50,9\%. Sejumlah penelitian pada beberapa spesies kerapu di antaranya adalah kerapu bebek, dilaporkan bahwa kebutuhan proteinnya antara 50,1\% -54,2\% (Giri et al., 1999; Rachmansyah et al., 2001), Epinephelus areolatus 60\% (Chu et al., 1996), E. malabaricus $47,8 \%-50,2 \%$ (Shiau \& Lan, 1996), dan E. striatus membutuhkan protein lebih dari $55 \%$ (Ellis et al., 1996). Ahmad et al. (1992) melaporkan bahwa kerapu lumpur, E. tauvina yang dipelihara dalam keramba jaring apung memerlukan pakan dengan protein 50\% pada energi sebesar $359 \mathrm{kkal}$ ME/100 g pakan. Dari beberapa hasil penelitian tersebut terlihat bahwa kebutuhan protein ikan kerapu di atas $40 \%$ dan respon untuk setiap spesies berbeda.

Tingginya kebutuhan protein pakan untuk kerapu khususnya kerapu macan dan kerapu bebek berimplikasi pada besarnya kebutuhan bahan baku pakan sumber protein terutama tepung ikan yang sampai saat ini masih sebagian besar diimpor. Sebagai konsekuensinya maka harga pakan ikan akan tinggi.

Upaya pemanfaatari bahan baku lainnya yang mempunyai kandurigan protein yang cukup tinggi perlu dilakukan sebagai alternatif sumber protein. Laining et al. (2003) melaporkan bahwa kerapu bebek dapat 
mencerna dengan baik protein yang berasal dari beberapa bahan baku lokal baik nabati maupun hewani, tetapi lebih mampu mencerna energi dari bahan hewani daripada bahan nabati. Berdasarkan informasi tersebut, perlu dilakukan penelitian untuk mengetahui seberapa besar bahan-bahan baku lokal tersebut, khususnya bahan nabati yang dapat dimanfaatkan oleh kerapu macan sebagai ikan karnivora sehingga kebutuhan protein yang tinggi dapat terpenuhi dengan tidak mengandalkan ikan rucah sebagai sumber makanan utamanya.

\section{KESIMPULAN}

Ikan kerapu macan ukuran antara $80--300 \mathrm{~g}$ membutuhkan kadar protein pakan sebesar 50,9\% dengan kadar lemak $9,7 \%$ dan total energi sebesar $4.575,1 \mathrm{kal} / \mathrm{g}$ untuk tumbuh secara maksimal. Perbedaan kandungan protein pakan tidak berpengaruh pada koefisien kecernaan bahan keringnya tetapi berpengaruh pada koefisien kecernaan proteinnya. Tingkat konsumsi pakan pada ikan kerapu macan dipengaruhi oleh ukuran ikan.

\section{DAFTAR PUSTAKA}

AOAC. 1990. In Official Methods of Analysis, $15^{\text {th }}$ edition. Association of Official Analytical Chemists, Washington D.C., p. 911--917.

Ahmad, T., M. Ardiarsyah, dan D. Ismunandar. 1992. Pengaruh pemberian pakan berkadar protein berbeda terhadap pertumbuhan kerapu lumpur, Epinephelus tauvina. J. Pen. Budidaya Pantai 8 (2): 71--80.

Boonyaratpalin, M. 1991. Nutritional studies on seabass (Lates calcarifer). In S.S. DeSilva (ed.). Fish Nutrition Research in Asia. Proceeding of the Fourth Asian Fish Nutrition Workshop. Asian Fish.Soc.Spec. Publ.5. Asian Fisheries Society, Manila. p. 33--42.

Chen, H.Y. and. J.C. Tsai. 1994. Optimal dietary protein level for the growth of juvenile grouper, Epinephelus malabaricus, fed semipurified diets. Aquaculture, 119: 265--271.

Chen, X., L. Lin, and H. Hong. 1995. Optimum content of protein in artificial diet for Epinephelus akaara. J. Oceanogr, 14: 407--412.

Chu, J.C.W., K.M.Y. Leung, and R.S.S. Wu. 1996. Nutritional study on the areolated grouper (Ephinephelus areolatus) culture in open sea cages. Proceeding the Pacon Conference on Suistanable Aquaculture, 11--14 June 1995. Honolulu, 79 pp.

Chua, T.E. and S.K. Teng. 1980. Economic production of estuary grouper, Epinephelus salmoides, Maxwell, reared in floating net cages. Aquaculture 20: 187-228.

Ellis, S., G. Viala, and W.O. Watanabe. 1996. Growth and feed utilization of hatchery-reared juvenil of nassau grouper fed four practical diets. Prog. Fish. Cult., 58: $167--172$.

Forster, I. 1999. A note on the method of calculating digestibility coefficients of nutrients provided by single ingredients to feed of aquatic animals. Aquaculture Nutrition, 5: 143--145.

Furukawa, A. and H. Tsukahara. 1966. On the acid digestion method for the determination of chromic oxides as an index substance in the study of digestibility of fish feed. Bulletin of Japanese Society of Fisheries, 32: 502--506.

Giri, N.A., K. Suwirya, and M. Marzuqi. 1999. Kebutuhan protein, lemak, dan vitamin C untuk yuwana ikan kerapu tikus (Cromileptes altivelis). J. Pen. Perikanan Indonesia, V(3): 38--46.

Halver, J.E. 1989. Fish Nutrition. Second Edition. Academic Press, Inc. San Diego. California. USA, 798 pp.

Hepher, B. 1988. Nutrition of Pond Fishes. Cambridge University Press. Cambridge USA, $388 \mathrm{pp}$.

Jobling, M. 1994. Fish Bioenergetics. Chapman \& Hall. London, $309 \mathrm{pp}$.

Laining, A., N.P. Palinggi, M. Atmomarsono, and T. Ahmad. 2002. L-ascorbyl-2-monophosphate- $\mathrm{Na}-\mathrm{Ca}$ as a dietary supplementary vitamin $\mathrm{C}$ source for sea cage reared humpback grouper, Cromileptes altivelis. Proceeding the $8^{\text {th }}$ Roche Aquaculture Centre in Asia Pacific, 28 November 2002 Bangkok, 118 pp.

Laining, A., Rachmansyah, T. Ahmad, and K.C. William. 2003. Apparent digestibility coefficients of several feed ingredients for humpback grouper, Cromileptes altivelis. Aquaculture, 218: 529--538.

National Research Council. 1981. Nutrient requirement of Domestic Animals. Number 2. Nutrient requirements of coldwater fishes. National Academic Press. Washington D.C., 63 pp.

National Research Council. 1993. Nutrient Requirement of Warmwater Fishes and Shellfishes. National Academic Press. Washington, D.C. 102 pp.

Rachmansyah, P.R. Pongmasak, A. Laining, dan A.G. Mangawe. 2001. Kebutuhan protein pakan bagi pembesaran ikan kerapu bebek, Cromileptes altivelis. J. Pen. Per. Indonesia, 7(4): 40--46.

Shiau, S.Y. and C.W. Lan. 1996. Optimum dietary protein level and protein to energy ratio for growth of grouper Ephinephelus malabaricus. Aquaculture, 145: 259-266.

Usman. 2002. Pengaruh Jenis Karbohidrat terhadap Kecernaan Nutrien Pakan, Kadar Glukosa, Efisiensi Pakan, dan Pertumbuhan Yuwana Kerapu Bebek, Cromileptes altivelis. Thesis Pascasarjana Institut Pertanian Bogor, 74 pp. 


\title{
KERUSAKAN JARINGAN IKAN NILA (Oreochromis niloticus) YANG TERINFEKSI PENYAKIT STREPTOCOCCIASIS
}

\author{
Hambali Supriyadi dan Oman Komarudin
}

\begin{abstract}
ABSTRAK
Tujuan penelitian adalah untuk mengetahui perubahan-perubahan histologis akibat infeksi Streptococciasis pada ikan nila Oreochromis niloticus. Ikan sampel dikoleksi dari sentra budi daya ikan di Tasikmalaya, Saguling, dan Cirata. Ikan sampel yang diambil terutama yang menunjukkan gejala terinfeksi Streptococciasis. Organ yang diambil untuk pengamatan histologis adalah hati, ginjal, limfa, dan otak; kemudian difiksasi dengan formalin buffer. Sampel kemudian diblok dengan menggunakan Paraplast dan setelah diiris kemudian diwarnai dengan pengecatan Haematoxyleen Ehrlich dan Eosin (H\&E). Hasil pengamatan menunjukkan bahwa kerusakan jaringan berupa lesi dan focal nekrosa terjadi pada limfa, serta inflamasi, rusaknya sel interstitial dan adanya infiltrasi bakteri terjadi pada ginjal. Sedangkan pada otak ditemukan adanya granuloma.
\end{abstract}

\begin{abstract}
A histological changes of some organs of nile tilapia (Oreochromis niloticus) infected by streptococciasis. By: Hambali Supriyadi and Oman Komarudin

The aim of this study is to know the histological changes of some organ of nile tilapia infected by streptococciasis. Fish samples were collected from ponds in Tasikmalaya, Saguling, and Cirata especially those indicating infected by Streptococciasis. The organs collected were liver, kidney, spleen, and brain. They were fixed in buffered formalin and embedded by using paraplast and stained with Haematoxyleen Ehrlich and Eosin (HE). The results indicated that focal necrotic occurred in the spleen, while inflamation of interstitial cell of kidney and infiltration of bacteria were found in kidney. Meanwhile granuloma was found in the central of stratum griseum of the brain.
\end{abstract}

KEYWORDS: $\quad$ histological changes, streptococciasis, Oreochromis niloticus

\section{PENDAHULUAN}

Budi daya ikan nila, khususnya nila GIFT di Indonesia pada saat ini sudah berkembang baik di kolam, keramba jaring apung (KJA), maupun tambak air payau berkadar garam rendah. Namun demikian akhirakhir ini sering terjadi gangguan penyakit yang banyak menimbulkan kematian.

Penelitian yang dilakukan pada tahun 1991/1992 telah membuktikan bahwa ikan nila dapat terinfeksi oleh bakteri Aeromonas hydrophila dan Enterobacter sp. (Supriyadi, 1992).

Baru-baru ini juga telah terjadi kematian ikan nila GIFT baik yang dipelihara di kolam, KJA, maupun tambak air payau. Ikan-ikan tersebut menunjukkan gejala klinis antara lain seperti mata menonjol, berenang berputar-putar, warna tubuh berubah (pucat/ gelap), dan kadang-kadang terdapat luka pada tubuhnya. Oleh karena itu dapat diduga bahwa kemungkinan salah satu penyebab kematian tersebut adalah akibat penyakit sreptococciasis.
Penyakit Streptococciasis merupakan salah satu penyakit yang relatif membahayakan pada ikan nila seperti dilaporkan di Amerika Serikat (Perera et al., 1994 dan Bowser et al., 1998), dan Jepang (Miyazaki et al., 1984). Sedangkan di Spanyol penyakit tersebut menginfeksi ikan turbot, Scopthalmus maximus (Toranzo et al., 1994).

Dengan adanya berbagai gejala klinis yang terjadi maka perlu diketahui organ-organ yang menjadi sasaran Streptococciasis. Hal ini dapat dipakai sebagai bahan dalam upaya pencegahan dan pengobatan yang tepat.

\section{BAHAN DAN METODE}

Ikan nila GIFT yang dipelihara di KJA yang menunjukkan gejala klinis seperti warna tubuh pucat, berenang berputar, dan mata menonjol dikoleksi dari beberapa sentra budi daya di Tasikmalaya, Saguling, dan Cirata. Untuk membuktikan adanya bakteri penginfeksi maka isolat diambil dari ginjal dan cairan otak dari ikan yang menunjukkan gejala infeksi 
streptococciasis. Isolat bakteri kemudian diidentifikasi dengan menggunakan metode standar sesuai dengan metode yang dikemukakan Amos (1985), Cowan (1985), dan Frerichs \& Millar (1993). Ikan sampel yang diambil dari masing-masing tempat yaitu sebanyak 20 ekor ikan untuk diisolasi bakterinya dan 5 ekor masing-masing untuk pemeriksaan histopatologi.

Organ tubuh ikan yang diambil adalah hati, ginjal, limfa, dan otak. Organ-organ tersebut dipisahkan dan difiksasi dalam larutan formalin buffer $10 \%$. Organ yang sudah difiksasi dibiarkan dalam larutan fiksatif minimal 24 jam, kemudian didehidrasi melalui alkohol secara seri meningkat dari $70 \%, 80 \%, 90 \%$, dan $100 \%$. Kemudian dihilangkan pengaruh alkoholnya (didealkoholisasi) dengan menggunakan khloroform, fenol, xylene, dan selanjutnya diinfiltrasi dan diblok dengan menggunakan paraplast. Blok organ dalam paraplast selanjutnya diiris dengan mikrotom pada ketebalan 5,0 $\mu$. Irisan jaringan diwarnai dengan pewarnaan Hematoxylene Ehrlich dan Eosin (H\&E), diletakkan pada gelas objek, dan direkat dengan menggunakan media perekat DPX. Irisan jaringan selanjutnya diamati di bawah mikroskop pada pembesaran 400 kali dan pengamatan kerusakan jaringan yang terjadi pada setiap irisan diambil fotonya.

\section{HASIL DAN BAHASAN}

Hasil identifikasi dengan menggunakan metode biokimia menunjukkan bahwa ikan nila yang dipelihara baik dalam kolam maupun di KJA ternyata terinfeksi oleh Streptococcus iniae, dengan kisaran prevalensi serangan di Tasikmalaya (80\%--100\%), Saguling $(90 \%)$, dan Cirata $(40 \%--50 \%)$. Gejala infeksinya antara lain meliputi ikan berenang berputar-putar (spinning or disorientation movement) dan warna tubuh berubah menjadi gelap/pucat. Pada beberapa ikan terlihat juga adanya pendarahan di sekitar anus. Ikan yang terinfeksi nampak sangat lemah dan akhirnya mati, namun di KJA terlihat juga ikan yang tidak memiliki gejala klinis yang menonjol tetapi ikan kemudian mati. Dari ikan yang menunjukkan gejala tersebut setelah dibedah (autopsi) terlihat adanya pembengkakan pada organ dalam seperti hati dan limfa. Hati berwarna pucat kebiruan, serta strukturnya sangat rapuh. Streptococcus iniae pertama kali ditemukan pada ikan Inia geoffrensis yang dipelihara di San Fransisco, California (Pier \& Madin, 1976 dalam Perera et al., 1994).

Pengamatan histologis pada limfa menunjukkan adanya kerusakan jaringan berupa nekrosa (focal necrosis) yang terdapat pada daerah red pulp. Pada tempat tersebut ditandai dengan adanya plasma yang mengalami lisis dan juga terlihat adanya sel makrofag yang berwarna agak kehitaman, seperti terlihat pada Gambar 1. Plasma sel terlihat keruh disertai dengan warna inti yang gelap (picnotic). Selain itu terlihat pula adanya daerah yang dipenuhi dengan sel-sel makrofag, yaitu sel fagosit yang biasanya menuju atau berada pada tempat infeksi (Gambar 2).

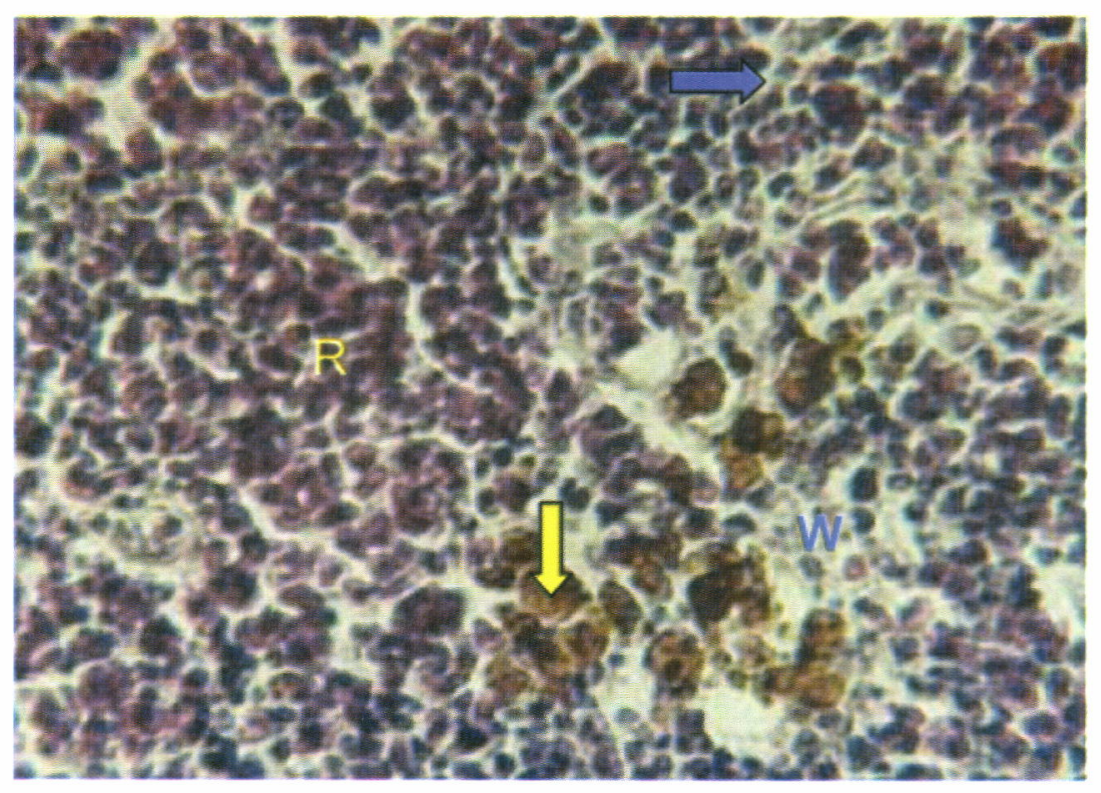

Gambar 1. Limfa ikan nila dengan red pulp (R) dan white pulp (W) serta daerah nekrosa (panah biru) dan selsel makrofag (panah h'ıning)

Figure 1. Spleen of nile tilapia with red pulp $(R)$ and white pulp $(W)$, necrotic area (blue arrow) and melanomacrophag centre (yellow arrow) 


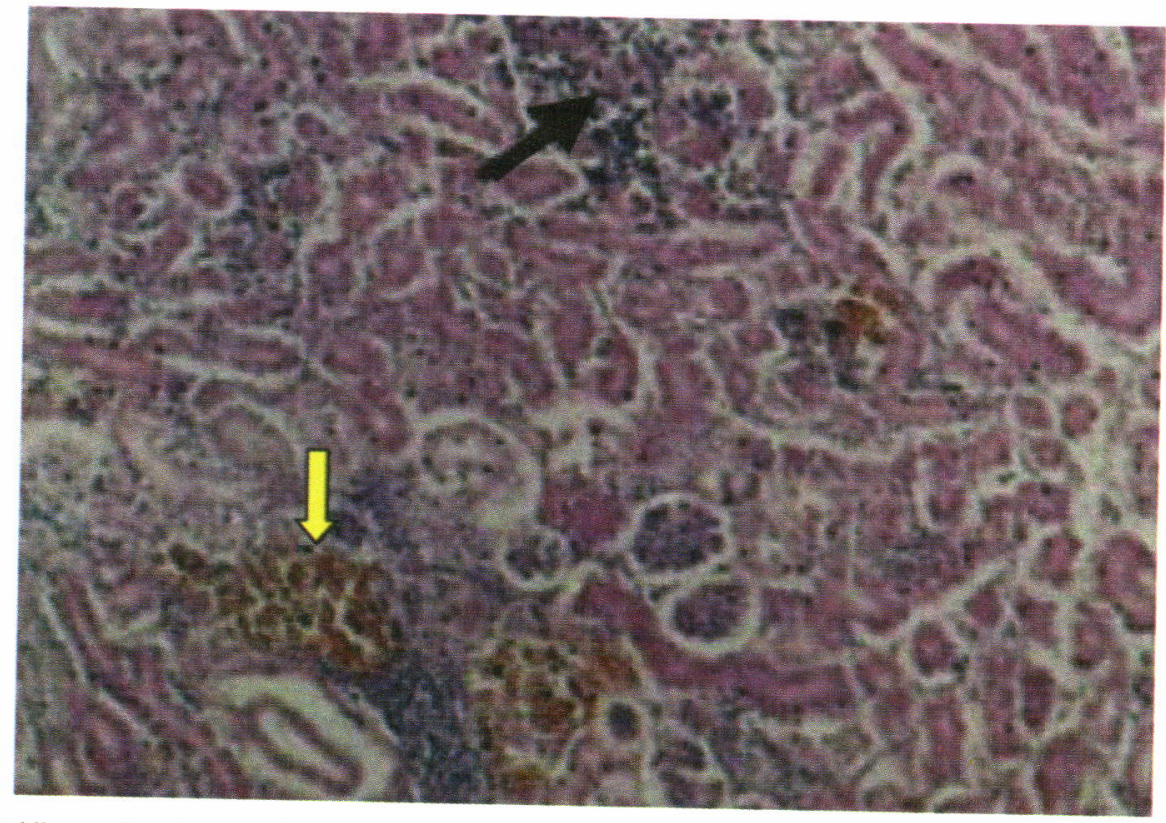
Gambar 2. Ginjal ikan nila dengan kerusakan sel interstitial (panah hitam) dan sentralisasi sel Makrofag (panah
kuning) Figure 2. Kidney of nile tilapia with degeneration of interstitial cells (black arrow) and Melanomacrophage
centre (yellow arrow)

Pengamatan pada ginjal menunjukkan adanya kerusakan pada jaringan pembuat darah (haemophoietic tissue), serta ditemukan infiltrasi bakteri pada sel interstitial ginjal.

Selain itu juga terlihat adanya sentralisasi sel-sel makrofag pada jaringan pembuat darah (haemophoietic tissue). Dengan adanya kerusakan pada jaringan pembuat darah yang terjadi pada ginjal maka hal ini lama kelamaan akan mengakibatkan ikan menderita kekurangan darah (anemia). Hal ini ditunjukkan dengan adanya perubahan pada warna tubuh menjadi pucat.
Selain warna tubuh pucat ikan yang terinfeksi penyakit ini juga dicirikan dengan insang dan hati yang berwarna pucat. Pergerakan ikan yang terinfeksi sangat lemah serta tidak responsif terhadap rangsangan.

Pengamatan pada otak menunjukkan adanya granuloma akibat infeksi streptococciasis pada stratum griseum pusat (Gambar 3). Dengan terdapatnya granuloma ini lebih meyakinkan lagi bahwa organ sasaran dari bakteri tersebut adalah otak. Miyazaki et al. (1984) juga menemukan hal yang sama pada otak ikan tilapia.

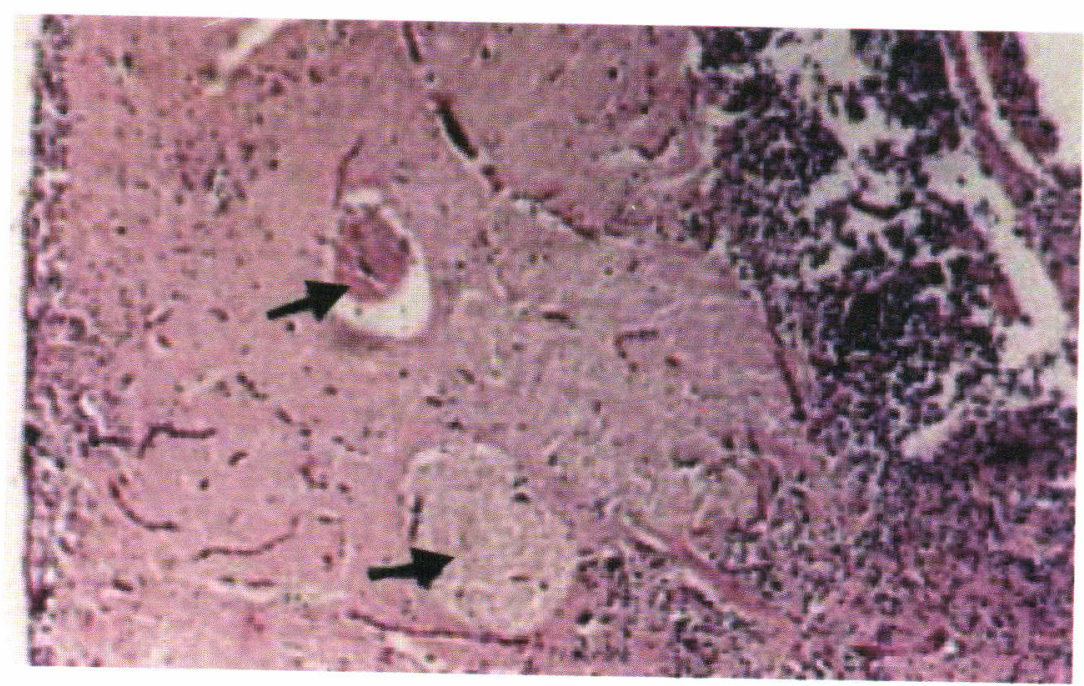

Gambar 3. Otak ikan nila dengan granuloma (tanda panah) pada daerah stratum griseum pusat Figure 3. Brain of nile tilapia with granuloma (arrow) located in stratum griseum central 
Adanya granuloma pada otak, tentu saja akan mengakibatkan terjadinya gangguan keseimbangan sehingga ikan yang terinfeksi penyakit ini akan menunjukkan gerakan berputar yang tidak terkontrol. Oleh karena itu maka ikan yang disampling adalah yang menunjukkan gejala klinis berenang berputar-putar. Dengan terganggunya otak dan beberapa organ yang sangat penting bagi ikan seperti ginjal dan limfa, maka akan mengganggu fungsi dari organ-organ tersebut. Selain keseimbangan ikan akan terganggu dengan adanya granuloma pada otak, maka proses produksi darah pun akan mengalami gangguan akibat terjadinya kerusakan pada ginjal dan limfa karena infeksi bakteri tersebut. Selanjutnya hal ini akan berpengaruh jelek bagi kesehatan ikan dan pada keadaan parah dapat menimbulkan kematian pada ikan.

\section{KESIMPULAN DAN SARAN}

Infeksi Streptococciasis menyebabkan terjadinya kerusakan jaringan pembuat darah dan dengan adanya infiltrasi bakteri pada otak mengakibatkan keseimbangan ikan terganggu.

\section{DAFTAR PUSTAKA}

Amos, K.H. 1985. Procedures for the detection and identification of certain fish pathogen. $3^{\text {rd }}$ ed. Fish Health Section, American Fisheries Society. Corvallis, Oregon. 114 pp.
Browser, P.R., G.A. Wooster, R.G. Getchell, and M.B Timmons. 1998. Streptococus innae infection of Tilapia, Oreochromis niloticus in recirculation production facility. J. of the World Aquaculture, 29(3): 335-339.

Cowan, S.T. 1985. Manual for the Identification of Medical Bacteria. Cambridge University Press. Cambridge. 238 pp.

Frerichs, G.N. and S.D. Millar. 1993. Manual for The Isolation and Identification of Fish Bacterial Pathogens. Pisces Press, Stirling, 58 pp.

Miyazaki, T.S.S. Kubota, N. Kaige, and T. Miyashita. 1984. A histological study of streptococcal disease in Tilapia. Fish Pathology. 19(3): 167--172.

Perera, R.P., S.K. Johnson, M.D. Collins, and D.H. Lewis. 1994. Streptococcus innae associated with mortality of Tilapia nilotica $\times T$. aurera hybrids. J. of Aquatic Animal Health. 6:335--340.

Supriyadi, H. 1992. Identifikasi dan cara penanggulangan pernyakit bakterial pada ikan nila. Pros. Seminar Hasil Pen. Perik. Air Tawar 1991/1992 Cipayung 20--22 Oktober 1992. Hambali Supriyadi et al. (eds.). Balai Penelitian Perikanan Air Tawar, Bogor. Pusat Penelitian dan Pengembangan Perikanan. Badan Penelitian dan Pengembangan Pertanian. p. 59--63.

Toranzo, A.E., S. Devesa., P. Herinen, A. Riaza, S. Nunez, and J.L. Barja. 1994. Streptococossis in culture turbot by an Enterococcus like bacterium. Bull. Eyr. Ass. Fish. Pathol. 14(1): 19--23. 